\title{
Recycling of Alum from Water Treatment Residue and Reuse It as a Flocculating Agent for Raw Water Treatment
}

\author{
Pascaline Sanga ${ }^{*}$, Yves Iradukunda ${ }^{1}$, Jean Claude Munyemana2* \\ ${ }^{1}$ College of Petrochemical Engineering, Lanzhou University of Technology, Lanzhou, China \\ ${ }^{2}$ University of Chinese Academy of Sciences, Lanzhou Institute of Chemical Physics, Chinese Academy of Sciences, Lanzhou, China \\ Email: *munyeclau2020@mails.ucas.ac.cn, *sanpassy90@gmail.com, i.yves05@gmail.com
}

How to cite this paper: Sanga, P., Iradukunda, Y., \& Munyemana, J. C. (2018). Recycling of Alum from Water Treatment Residue and Reuse It as a Flocculating Agent for Raw Water Treatment. Journal of Geoscience and Environment Protection, 6, 216-226.

https://doi.org/10.4236/gep.2018.612018

Received: November 3, 2018

Accepted: December 26, 2018

Published: December 29, 2018

Copyright $\odot 2018$ by author s and Scientific Research Publishing Inc. This work is licensed under the Creative Commons Attribution International License (CC BY 4.0).

http://creativecommons.org/licenses/by/4.0/

(c) $\underset{\mathrm{EY}}{\mathrm{C}}$ Open Access

\begin{abstract}
The chemical coagulation-flocculation technology is touted as one of the valuable techniques and widely used for wastewater treatment because of its simplicity and effectiveness. So far, a number of flocculants have been fabricated to ameliorate the flocculation process in water treatment such as alum, polyaluminium chloride. Despite its broad application in water treatment, accumulation of alum in sludge has been reported as the main source of a disposal problem. Furthermore, recent studies suggested that the presence of alum in sludge may lead to human health problems. Here in, we have used alkalization method to recover alum present in sludge collected from Kimisagara water treatment plant located in Kigali capital city of Rwanda. The recovered alum was used more than one time and showed excellent flocculation efficiency. Some physical parameters such as $\mathrm{pH}$, Total Suspended Solids (TSS), Total Dissolved Solids (TDS), Conductivity and Turbidity were systematically tested and compared with those of World Health Organization (WHO) and Rwanda Standards Board (RSB) standards for drinking water. The results showed that alum present in sludge can be recovered and reused for multiple times.
\end{abstract}

\section{Keywords}

Sludge, Alum, Flocculation, Turbidity, Kimisagara

\section{Introduction}

One of the country's development indicators is the availability of safe and clean drinking water. Previously WHO/UNICEF report has shown that almost 663 
million of the population all over the world don't have an access to safe drinking water (Wondimu, 2016). The safety of the drinking water is globally controlled by international guidelines set by WHO and as well implemented by the national institute of standardization in some countries. The availability of safe and low-cost drink water by 2030 is one of the important goals of the Sustainable Development Goals of the United Nations (SDG6) (United Nations, 2018). Therefore, the progress in water treatment technologies plays a crucial role to reach this goal.

So far, several traditional and advanced techniques have been developed and used to treat wastewater including ion exchange, precipitation, membrane filtration, flotation, adsorption, solvent extraction, coagulation, and flocculation (Gunatilake, 2015). Among these techniques, coagulation/flocculation is one of the most broadly used to remove suspended and dissolved solids, colloids and organic material from wastewater (Raimon \& Said, 2017). Coagulation and flocculation are the essential pre-treatment technique employed by water industries around the world for water treatment (Joshi \& Shrivastava, 2011). The effectiveness of coagulation depends on many factors including the applied coagulating agents, the dosage, the solution $\mathrm{pH}$ and the concentration and the nature of the organic compounds present in water (Sher, Malik, \& Liu, 2013). The widely used coagulants are iron, poly aluminium chloride, and alum salts. These coagulants promote particles agglomeration by reducing the electrostatic particle surface charges in the acidic $\mathrm{pH}$ region prominently where hydrolyzed metal species are abundant (Sher, Malik, \& Liu, 2013). However, aluminum salts are an excellent commonly used coagulant to reduce so many particles from wastewater, but it is still challenging to deal with the wastes (sludge) produced after the treatment.

During water treatment where alum is used as a flocculant, Aluminum reacts with water by forming an insoluble aluminum hydroxide floc which removes the fine suspended and colloidal impurities and leads to a production of a huge amount of alum sludge (Joshi \& Shrivastava, 2011). The produced alum sludge can be a source of toxic aluminum that may cause many serious environmental problems such as water pollution, changes in soil properties and leachate chemistry (Kluczka, Zo, \& Ciba, 2017). Furthermore, previous researches have also reported that aluminium has a potential link to Alzheimer's disease (Niquette et al., 2004). Aluminum is indeed known to be the cause of the toxicity of the marine habit. Many studies have revealed a remarkable toxicity of aluminum on fishes (Price, 2013). Aluminum in water has proven to be responsible for chronic toxicity in various species such as sub-lethal effects of a reduction in appetite, metabolism, and behavior in rainbow trout (Oncorhynchus mykiss) and polychaetous annelids (EPA, 2005). All of these previous studies have shown that alum or aluminum content in environment would lead to the serious environmental pollution.

The reuse of chemical sludge can be employed to minimize the coagulant usages or to increase the removal efficiencies (Jangkorn et al., 2011). Recent stu- 
dies have shown that the alum sludge is used at the concentrations of $100-180$ $\mathrm{mg} / \mathrm{L}$ to improve the removal efficiency of lead from $79 \%$ to $96 \%$ - $98 \%$ resulting in the reduction of fresh alum from $175 \mathrm{mg} / \mathrm{L}$ to $50.0-12.5 \mathrm{mg} / \mathrm{L}$ (Chu, 1999) and to remove the hydrophobic dye from the textile wastewater at the removal efficiency of $88 \%$, resulting in the reduction of fresh alum requirement by one-third (Chu, 2001). According to the previous literature, the main methods used to recover the alum from the disposal of water treatment residual include acidification, alkalization, membrane separation and ion exchange (Xu et al., 2009). Since aluminum hydroxide $\mathrm{Al}(\mathrm{OH})_{3}$ is an amphoteric compound, it can be dissolved in an acidic or alkaline solution. It also reacts with an acid to form soluble aluminum ions (Joshi \& Shrivastava, 2011).

The aim of this study as shown in the flowchart (Figure 1) is to recover alum from water treatment residue collected from water treatment plant and reuse it as a flocculant agent for water treatment. We have used alkalization approach to extract alum from sludge and reuse it to treat water. This study proves that alum present in sludge can be importantly recovered and reused which may reduce the risk of environmental pollution as well as cost saving to access to safe and clean water.

\section{Materials and Methods}

\subsection{Sample Collection and Characterization}

The samples were collected from Kimisagara water treatment plant located in Kigali capital city of Rwanda. At the treatment plant, after flocculation the sludge was discharged in two different sedimentation tanks. The sludge samples were collected from those two different sedimentation tanks. The raw water sample with brown color from Yanze River situated in Kanyinya Sector, Nyarugenge District, was taken at raw water tank. Table 1 summarizes the characteristics of the collected raw water before treatment.

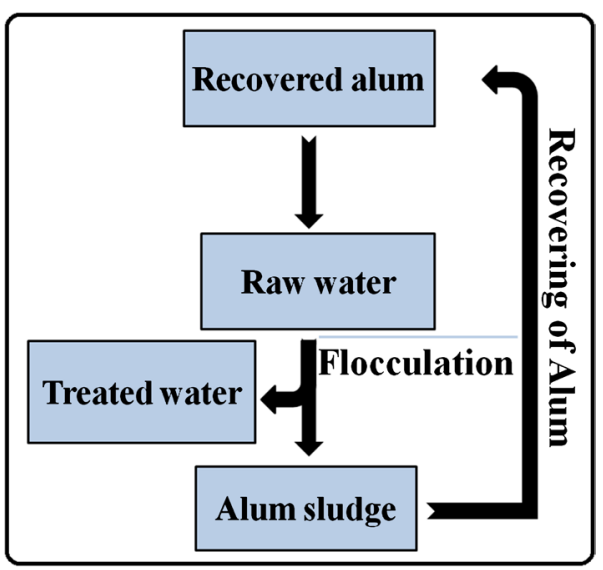

Figure 1. Flowchart showing the alum recovering and reuse. This flowchart indicated how alum in sludge after being recovered was introduced to the raw water as flocculants agent. For every cycle alum is extracted from the produced sludge and then used for further water treatment. 
Table 1. Characteristics of raw water.

\begin{tabular}{ccc}
\hline Parameters & Units & values \\
\hline PH & & 7 \\
Turbidity & NTU & 89.7 \\
Conductivity & $\mu s$ & 378.5 \\
TDS & $\mathrm{mg} / 1$ & 190.5 \\
TSS & $\mathrm{mg} / \mathrm{l}$ & 5 \\
\hline
\end{tabular}

\subsection{Sludge Pretreatment}

To allow aluminum released from the sludge, $2 \mathrm{~g}$ of alum sludge were accurately weighed and dissolved with $5 \mathrm{~mL}$ mixture of concentrated nitric acid and perchloric acid in $2: 1(\mathrm{v} / \mathrm{v})$ portion followed by gentle boiling at $60^{\circ} \mathrm{C}$ in 15 minutes, then at $120^{\circ} \mathrm{C}$ for 75 minutes in a hood. The solution was cooled, filtered and dilute to $200 \mathrm{~mL}$.

\subsection{Determination of Aluminum Concentration in Sludge}

For the calibration of Inductively Coupled Plasma Emission (ICPE) machine (ICPE-9800, Japan), $49.42 \mathrm{~g}$ of $\mathrm{AlCl}_{3}$ were weighed and dilute to $100 \mathrm{~mL}$ with distilled water. It was labeled properly as $100 \mathrm{ppm}$ (parts per million) $\mathrm{Al}^{3+}$. From this solution $0.05,0.10,0.20,0.30$ and $0.50 \mathrm{~mL}$ aliquots were pipetted into 5 cleaned volumetric flask and dilute to $25.0 \mathrm{~mL}$ with deionized water. These solutions gave 0.2 to $2.0 \mathrm{ppm}$ of $\mathrm{Al}^{3+}$. Their absorbance was taken using ICPE and the machine gave the calibration curve for $\mathrm{Al}^{3+}$. The amount of $\mathrm{Al}^{3+}$ was determined in our digested sample per $100 \mathrm{~mL}$ of a solution in ppm (mg/L). This determination was repeated and the average was reported.

\subsection{Recover of Alum Using Alkalization Method}

Alum was extracted from sludge following the previously reported techniques (Abdo, Ewida, \& Youssef, 1993). In brief, since aluminium is present in sludge in form of hydroxide, the sludge was treated by $\mathrm{NaOH}$ to bring back alum in solution in form of sodium aluminate $\left(\mathrm{NaAlO}_{2}\right)$ (reaction 1). Since the produced sodium aluminate hasn't enough coagulant properties as sodium aluminium sulfate so sufficient amount of sulphuric was added to produce aluminium sulfate and also adjust the $\mathrm{pH}$.

$$
\mathrm{Al}(\mathrm{OH})_{3}+\mathrm{NaOH} \rightarrow \mathrm{NaAlO}_{2}+2 \mathrm{H}_{2} \mathrm{O}
$$

\subsection{Flocculation Process}

Raw water flocculation was carried out by mixing water from Yanze River collected at water treatment plant with different volumes of the recycled alum. In brief, $50 \mathrm{~mL}$ of raw water was poured in 3 beakers of $200 \mathrm{~mL}$ and stirred by a magnetic bar to make the solution homogeneous followed by addition of $10 \mathrm{~mL}$, $30 \mathrm{~mL}$, and $50 \mathrm{~mL}$ for each beaker. The debris residues were deposited on the 
bottom of beaker as a result of flocculation. These experiments were done in duplicate and the presented data was calculated by the average of two parallel experiments.

\section{Result and Discussion}

\subsection{Recovery of Alum from Sludge}

The amount of aluminium in sludge from water treatment plant was 2877.5 $\mathrm{mg} / \mathrm{l}$. The alum was recovered from sludge for every cycle by alkalization method (Figure 2) and the amount of aluminium within recovered alum was tested using ICPE. The result shows that aluminium content in sludge decreases with increasing the number of cycles. All of these findings clearly show that alum content in the sludge can be extracted and used again.

\subsection{The Change of $\mathrm{pH}$ with the Addition of Recovered Alum}

$\mathrm{pH}$ is a measure of the relative amount of free hydrogen $\left(\mathrm{H}^{+}\right)$and hydroxyl ions $\left(\mathrm{OH}^{-}\right)$, the $\mathrm{pH}$ of water is a measurement of how acidic or how basic the water is, the range goes from 0 to 14 , and around 7 is considered neutral (Singer, George, \& Childers, 2012). pH is among important parameters of many chemical

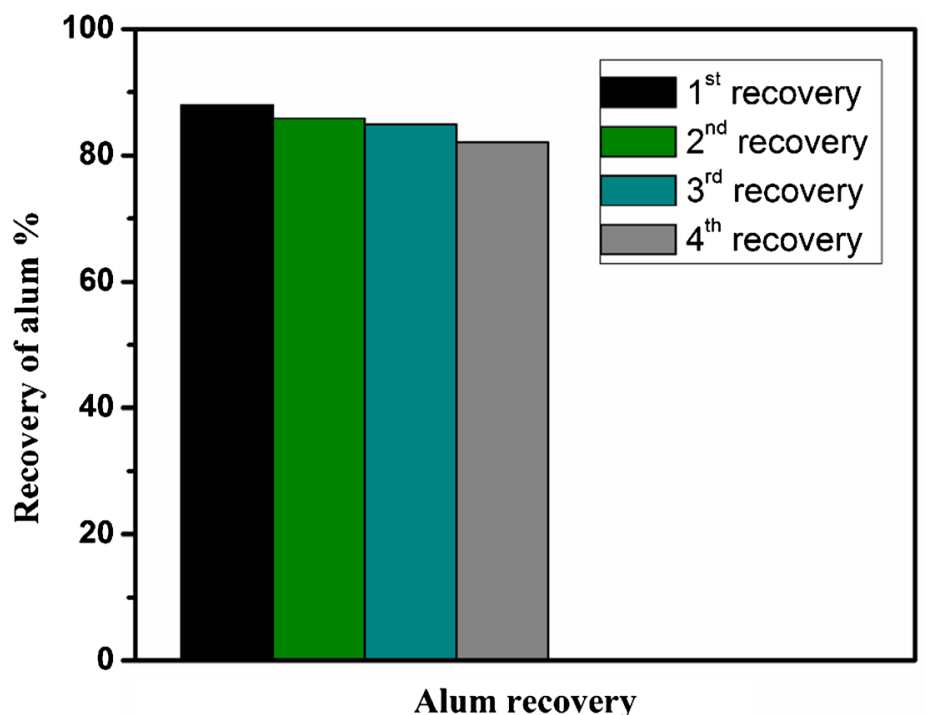

Figure 2. Alum recovery for four continuous recycling.

Table 2. RSB and WHO standard for drinking water.

\begin{tabular}{ccccc}
\hline Parameters & Unity & $\begin{array}{c}\text { WHO standards } \\
(\text { WHO, 2011) }\end{array}$ & $\begin{array}{c}\text { RSB standards } \\
(\text { RS2, 2012) }\end{array}$ & Our results \\
\hline $\mathrm{pH}$ & - & $6.5-8.5$ & $6.5-8.5$ & 7 \\
TSS & $\mathrm{mg} / \mathrm{l}$ & Not detectable & Not detectable & 0.4 \\
Turbidity & $\mathrm{NTU}$ & 5 max. & 5 max. & 1.2 \\
TDS & $\mathrm{mg} / \mathrm{l}$ & $600-1000$ & 700 & 125 \\
Conductivity & $\mu \mathrm{S} / \mathrm{cm}$ & 1500 & - & 255 \\
\hline
\end{tabular}


reactions. For instance, several marine environment reactions are monitored by the $\mathrm{pH}$ change (Das \& Mangwani, 2015). Furthermore, exposure to a high value of $\mathrm{pH}$ has shown to lead to life risk such as exacerbation skin disorder and irritation of eyes. Exposure to extremely low $\mathrm{pH}$ values has also witnessed many health problems including redness and irritation of eye and deterioration of the epithelium (Gunatilake, 2015). In addition, because $\mathrm{pH}$ has great influences on corrosion reaction of the metals it may also contain some indirect effect of health (Durowaye et al., 2015). Even if pH does not have a direct effect on water users, but it is still considered as one of the remarkable handling of water-quality parameters. Therefore, a big attention has to be paid to $\mathrm{pH}$ control for all steps of water treatment by ensuring the water clarification and disinfection. We have investigated the $\mathrm{pH}$ changes along the recycling process (Figure 3). Our experimental results have shown that, the $\mathrm{pH}$ change as the number of cycles changes. The slight change of $\mathrm{pH}$ as stayed in the range of $7-7.7$ and the slight change 0.7 unit probably because of the presence of sulfate ions contained in the flocculating solutions which are a basic ions. The $\mathrm{pH}$ obtained after flocculation was in the range of WHO and RSB drinking water standards, confirming that the treated water may be used without any doubt of contamination caused by a high level of acidity or alkalinity.

\subsection{Effect of Recovered Alum on the Removals of TSS}

Total suspended solids (TSS) are water quality parameter that is defined as the quantity of material suspended in a known volume of water that is trappable in a filter. These materials are mostly from different origin including animal and plant mater industrial and home wastes, etc. (Yusoph et al., 2018). High concentrations of suspended solids in water can cause many problems for stream health and aquatic life (Marla Sheffer, 2003). As shown in Figure 4, the number of suspended

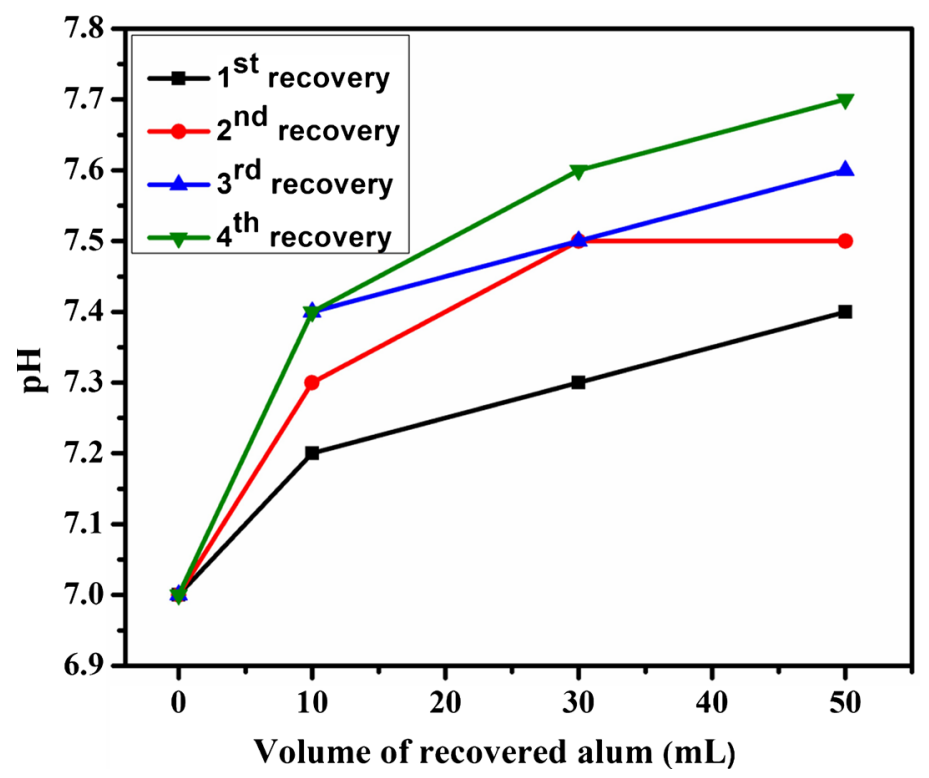

Figure 3. The change of $\mathrm{pH}$ during alum recovering. 


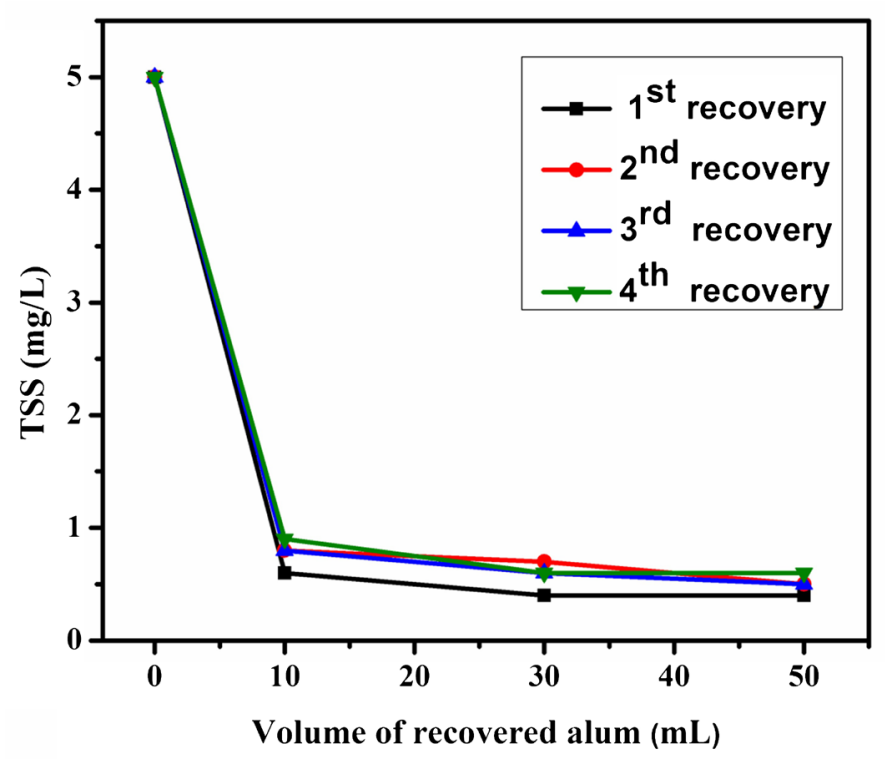

Figure 4. Effect of recovered alum on the TSS removal.

matters in raw water was reduced to a significant extent after the flocculation with recovered alum. TSS removal efficiency increased with the increase the flocculant when the doses of flocculant were $10 \mathrm{~mL}$, the TSS was about $0.6 \mathrm{mg} / \mathrm{l}$ but it decreased to $0.4 \mathrm{mg} / \mathrm{L}$ when the doses increase to $50 \mathrm{~mL}$. The TSS removal also decreases with the number of recovered times, for the first recovery, the TSS was $0.4 \mathrm{mg} / \mathrm{L}$ which was increased to $0.6 \mathrm{mg} / \mathrm{L}$ for the fourth recovery. For all cycles, the result indicated that the recovered alum are capable to reduce the TSS from raw water.

\subsection{Effect of Recovered Alum on the Removals of Turbidity}

Turbidity is the measure of relative clarity of a liquid. It is an optical characteristic of water and is an expression of the amount of light that is scattered by material in the water when a light is shined through the water sample (Lloyd, Koenings, \& Jacqueline, 2013). Turbidity as a property of the clarity of a liquid, it is among parameter that has mentioned by WHO as an indicator of safe drinking water (Table 2). There are several materials that make water to be turbid such as organic and inorganic colored matter, plankton and other microscopic organisms (Myre \& Shaw, 2006). Much cloudiness caused by turbidity in drinking water has reported being health concern such as promoting pathogens growth on water distributing tools system. We have used the recovered alum to remove the turbid from raw water (Figure 5). As indicated in Figure 5, the recovered alum has impressively removed the turbidity elements and put it to the range of WHO and RSB range for drinking water quality. It is shown in graph 5 that the turbidity removal increased with the increase in coagulant. When the doses of coagulant was $10 \mathrm{~mL}$, the turbidity was about 1.5 NTU but it decreased to $1.2 \mathrm{NTU}$ when the doses increase to $50 \mathrm{~mL}$. The recovered alum solution has shown the high capacity to remove the turbidity to the acceptable value of drinking 


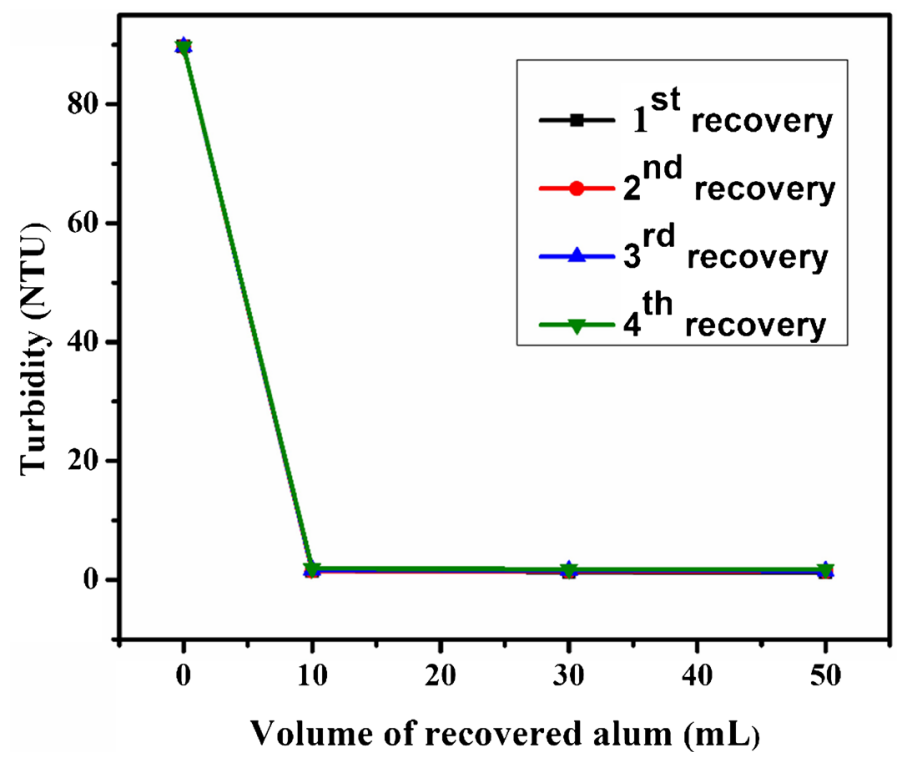

Figure 5. Effect of recovered alum on the removals of turbidity.

water. The turbidity removal also decreases with the number of recovered times for the first recovery the turbidity was 1.2 NTU which was increased to 1.8 NTU for the fourth recovery. All the values are in the permissible range ( $<5 \mathrm{NTU})$ as drinking water standards which shows that the flocculation was successful and impurities were reduced.

\subsection{Effect of Recovered Alum on Conductivity and TDS}

Total Dissolved Solids (TDS) is defined as all inorganic and organic substances contained in water that can pass through a 2-micron filter. In general, it is the sum of the cations and anions (include calcium, magnesium, sodium, potassium, carbonate, bicarbonate, chloride, fluoride, sulfate, phosphate, and nitrate) in water (Islam et al., 2016), while Conductivity refers to the number of dissolved solids in water. It actually measures the ionic process of a solution that enables it to transmit current (Meride \& Ayenew, 2016). The relationship between TDS and Electrical conductivity (EC) is a function of the type and nature of the dissolved ions (cations and anions) in the water (Thirumalini \& Joseph, 2009). TDS cause toxicity through increases in salinity, changes in the ionic composition of the water and toxicity of individual ions. If the concentration of TDS and conductivity are high or low, it may affect many forms of aquatic life (Scannell \& Jacobs, 2001). The effects of recovered alum on conductivity and TDS were investigated for four continuous recovery cycles. As shown in Figure 6, it is clear that after the flocculation the conductivity and TDS decrease with the increase of flocculants. when the flocculants increase from $10 \mathrm{~mL}$ to $50 \mathrm{~mL}$ the TDS and conductivity decrease from $127.6 \mathrm{mg} / \mathrm{L}$ to $125 \mathrm{mg} / \mathrm{L}$ (Figure 6(a)) and 256.8 $\mu \mathrm{s} / \mathrm{cm}$ to $255 \mu \mathrm{s} / \mathrm{cm}$ (Figure $6(\mathrm{~b})$ ) respectively, But the conductivity and TDS were increasing with the number of recovered times because of increasing the ions in the recovered solution due to the high concentration of ions in raw 
(a)

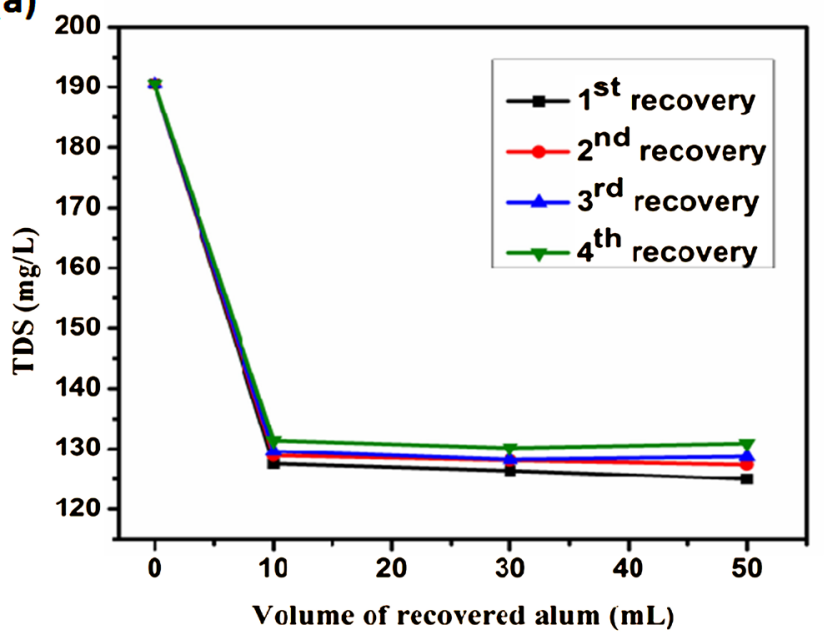

(b)

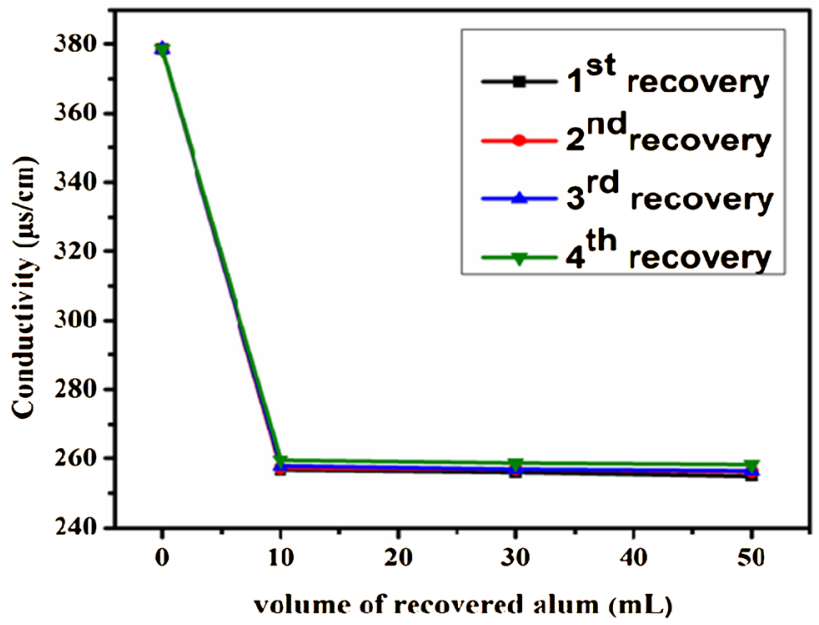

Figure 6. Effect of recovered alum on (a) TDS, (b) conductivity.

water. From the first recovery to the fourth recovery, the conductivity and TDS increase from $255 \mu \mathrm{s} / \mathrm{cm}$ to $258.2 \mu \mathrm{s} / \mathrm{cm}$ and $125 \mathrm{mg} / \mathrm{L}$ to $130.9 \mathrm{mg} / \mathrm{L}$ respectively which may reach drinking water standard values after all water treatment process.

\section{Conclusion}

Alum is widely used as coagulant for treatment of raw water in most of water treatment plant. The sludge formed from these water treatment activities is disposed as waste and costs a huge amount of money for dealing with this waste sludge. We have used alkalinisation methods to extract alum from sludge. The main purpose of this study was to recover alum from water treatment residue and use it as flocculants for further water treatment. The experimental results showed that sludge collected from Kimisagara water treatment plant located in Kigali, the capital city of Rwanda contains a significant amount of aluminum $(2877.5 \mathrm{mg} / \mathrm{l})$ that could be recovered and be reused as flocculants agent for further use. The recovered alum has shown an excellent capacity to improve the quality of raw water in the way that some parameters such as TDS, turbidity and conductivity values dropped up to the range values of the drinking water standards as established by WHO and RSB. Recovering alum from water treatment residue is indubitably reducing the environmental pollution caused by alum sludge and would also reduce the cost of purchasing alum since the recovered alum could be used for several times.

\section{Conflicts of Interest}

The authors declare no conflicts of interest regarding the publication of this paper.

\section{References}

Abdo, M. S. E., Ewida, K. T., \& Youssef, Y. M. (1993). Recovery of Alum from Wasted

Sludge Produced from Water Treatment Plants. Journal of Environmental Science and 
Health. Part A: Environmental Science and Engineering and Toxicology, 28, 1205-1216.

Chu, W. (2001). Dye Removal from Textile Dye Wastewater Using Recycled Alum Sludge. Water Research, 35, 3147-3152. https://doi.org/10.1016/S0043-1354(01)00015-X

Chu, W. E. I. (1999). Lead Metal Removal by Recycled Alum Sludge. Water Research, 33, 3019-3025. https://doi.org/10.1016/S0043-1354(99)00010-X

Das, S., \& Mangwani, N. (2015). Ocean Acidification and Marine Microorganisms: Responses and Consequences. Oceanologia, 57, 349-361. https://doi.org/10.1016/j.oceano.2015.07.003

Durowaye, S. I., Alabi, A. G. F., Sekunowo, O. I., Bolasodun, B., \& Rufai, I. O. (2015). Effects of $\mathrm{pH}$ Variation on Corrosion of Mild Steel in Bore-Hole Water Using 1M Sodium Hydroxide Solution Effects of $\mathrm{pH}$ Variation on Corrosion of Mild Steel in Bore-Hole Water Using 1M Sodium Hydroxide Solution. International Journal of Engineering and Technology, 4, 139-144.

EPA (2005). EPA-822-R-05-005: Aquatic Life Ambient Water Quality Criteria Nonylphenol. http://www.epa.gov/waterscience/criteria/aqlife.html

Gunatilake, S. K. (2015). Methods of Removing Heavy Metals from Industrial Wastewater. Journal of Multidisciplinary Engineering Science Studies, 1, 12-18.

Islam, M. R., Khairul, M., Sarkar, I., Afrin, T., \& Khaleque, A. (2016). A Study on Total Dissolved Solids and Hardness Level of Drinking Mineral Water in Bangladesh. American Journal of Applied Chemistry, 4, 164-169. https://doi.org/10.11648/j.ajac.20160405.11

Jangkorn, S., Kuhakaew, S., Theantanoo, S., Klinla-or, H., \& Sriwiriyarat, T. (2011). Evaluation of Reusing Alum Sludge for the Coagulation of Industrial Wastewater Containing Mixed Anionic Surfactants. Journal of Environmental Sciences, 23, 587-594. https://doi.org/10.1016/S1001-0742(10)60451-2

Joshi, S., \& Shrivastava, K. (2011). Recovery of Alum Coagulant from Water Treatment Plant Sludge: A Greener Approach for Water Purification. International Journal of Advanced Computer Research, 1, 101-103.

Kluczka, J., Zo, M., \& Ciba, J. (2017). Assessment of Aluminum Bioavailability in Alum Sludge for Agricultural Utilization. Environmental Monitoring and Assessment, 189, 422.

Lloyd, D. S., Koenings, J. P., \& Jacqueline, D. (2013). Effects of Turbidity in Fresh Waters of Alaska. North American Journal of Fisheries Management, 7, 37-41.

Marla, S. (2003). pH in Drinking-Water (Vol. 2). WHO Guidelines for Drinking-Water Quality. World Health Organization. http://www.who.int/water_sanitation_health/dwq/chemicals/ph.pdf

Meride, Y., \& Ayenew, B. (2016). Drinking Water Quality Assessment and Its Effects on Residents Health in Wondo Genet Campus, Ethiopia. Environmental Systems Research, 5, 1. https://doi.org/10.1186/s40068-016-0053-6

Myre, E., \& Shaw, R. (2006). The Turbidity Tube: Simple and Accurate Measurement of Turbidity in the Field.

Niquette, P., Monette, F., Azzouz, A., \& Hausler, R. (2004). Impacts of Substituting Aluminum-Based Coagulants in Drinking Water Impacts of Substituting Aluminum-Based Coagulants in Drinking Water Treatment. Water Quality Research Journal of Canada, 39, 303-310.

Price, M. H. H. (2013). Sub-Lethal Metal Toxicity Effects on Salmonids: A Review (p. 64). Report Prepared for Skeena Wild Conservation Trust. 
RS2 (2012). Potable Water Specification (2nd ed.). Kigali: Rwanda Bureau of Standard.

Raimon \& Said, M. (2017). Laboratory Effluent Treatment by Using Coagulant Alum sulphate and Poly Aluminium Chloride (PAC). Indonesian Journal of Fundamental and Applied Chemistry, 47-51.

Scannell, P. W., \& Jacobs, L. L. (2001). Effects of Total Dissolved Solids on Aquatic Organisms. Alaska Department of Fish and Game Division of Habitat and Restoration.

Sher, F., Malik, A., \& Liu, H. (2013). Industrial Polymer Effluent Treatment by Chemical Coagulation and Flocculation. Journal of Environmental Chemical Engineering, 1, 684-689. https://doi.org/10.1016/j.jece.2013.07.003

Singer, M. J., George, H. A., \& Childers, C. D. (2012). What Is pH and Why Do We Care (pp. 1-3).

Thirumalini, S., \& Joseph, K. (2009). Correlation between Electrical Conductivity and Total Dissolved Solids in Natural Waters. Malaysian Journal of Science, 28, 55-61. https://doi.org/10.22452/mjs.vol28nol.7

United Nations (2018). Executive Summary Sustainable Development Goal 6 Synthesis Report 2018 on Water and Sanitation. https://doi.org/10.1002/net.20371

WHO (2011). Guidelines for Drinking Water Quality (4th ed.). Water Quality Standards. Geneva: World Health Organization.

Wondimu, M. (2016). Examining the Impact of Household Access to Water and Sanitation on Child Malnutrition in Ethiopia.

Xu, G. R., Yan, Z. C., Wang, Y. C., \& Wang, N. (2009). Recycle of Alum Recovered from Water Treatment Sludge in Chemically Enhanced Primary Treatment. Journal of Hazardous Materials, 161, 663-669.

Yusoph, M., Diate, K., Baulo, A., \& Herbito, J. (2018). Do-It-Yourself Total Suspended Solids (TSS) Filtration Apparatus Total Suspended Solids (TSS) (pp. 1-12). University Iligan Institute of Technology. 